\title{
Identification and Characterization of Pythium Species Associated with Greenhouse Floral Crops in Pennsylvania
}

\author{
G. W. Moorman, S. Kang, and D. M. Geiser, Department of Plant Pathology, The Pennsylvania State University, \\ University Park, PA 16802-4506; and S. H. Kim, Bureau of Plant Industry, Pennsylvania Department of Agricul- \\ ture, 2301 N. Cameron St., Harrisburg, PA 17110-9408
}

\begin{abstract}
Moorman, G. W., Kang, S., Geiser, D. M., and Kim, S. H. 2002. Identification and characterization of Pythium species associated with greenhouse floral crops in Pennsylvania. Plant Dis. 86:1227-1231.

During 1996 to 2001, samples submitted to clinics from commercial greenhouses involved 11 species and two unidentified isolates of Pythium from 110 plant samples, five potting soil tests, and five tests of irrigation water. Pythium irregulare was found in $45 \%$ of the plant samples, four of the five water samples, and three of the five potting soils. Pythium aphanidermatum accounted for $29 \%$ of all plant but $77 \%$ of the poinsettia samples. The Pelargonium samples received were infected with $P$. aphanidermatum, $P$. dissotocum, $P$. heterothallicum, group $\mathrm{F}, P$. irregulare, $P$. myriotylum, and P. ultimum. The base pair sequence of the ITS1, 5.8S, and ITS2 regions of ribosomal DNA effectively differentiated the species encountered. The ras-related protein gene sequence did not differentiate $P$. aphanidermatum, $P$. arrhenomanes, and $P$. deliense from one another. One isolate each of $P$. cylindrosporum, $P$. dissotocum, $P$. heterothallicum, $P$. splendens, and $P$. ultimum exhibited resistance to the phenylamide fungicide mefenoxam, an isomer of metalaxyl, while $38 \%$ of the P. aphanidermatum and $37 \%$ of the $P$. irregulare isolates were resistant.
\end{abstract}

Species of the plant-pathogenic organism Pythium are worldwide in distribution $(23,24,51)$, and almost all greenhouse crops are susceptible to one or more species $(18,39,47,49)$. In Pennsylvania and other floricultural crop production areas in the United States, Pythium-caused root, stem, and cutting rots and damping-off result in losses every season, particularly in potted plants. Knowing the identity of the pathogen, where it is harbored, how it may have entered the greenhouse production system, and its sensitivity to fungicides can be crucial to formulating effective, longterm management strategies.

Some Pythium species are well recognized as virulent plant pathogens, while others appear to be weak pathogens or saprophytes $(14,15)$. Although most species readily form zoospores, making them a potential threat in greenhouse irrigation systems that recycle water, others rarely form zoospores. Despite these concerns, isolates are seldom identified to the species level in a clinic situation because of the time and experience needed to produce and examine the zoosporangia, oogonia, and antheridia required to determine species

Corresponding author: G. W. Moorman

E-mail: gmoorman@psu.edu

Accepted for publication 10 June 2002.

Publication no. D-2002-0822-01R

(C) 2002 The American Phytopathological Society
$(16,38,51,53,54)$. Attempts have been made to simplify identification by applying techniques, including starch gel electrophoresis of total cellular protein and staining techniques $(12,13)$, isoelectric focusing of soluble protein (1), protein banding patterns (9), and isozyme analysis (3). DNA analysis methods have included $\mathrm{G}+$ $\mathrm{C}$ content of chromosomes and mitochondrial DNA, the banding ratios in cesium chloride bisbenzimide density gradients for chromosomal, ribosomal, and mitochondrial DNA, chromosome DNA yield, hyperchromicity of DNA, and the size of the rDNA repeat unit (4). Random amplified polymorphic DNA (RAPD) methodology (25), restriction fragment length polymorphisms (RFLP) of total DNA (31), mitochondrial DNA RFLP $(33,34,36,37)$, and polymerase chain reaction (PCR) amplification of the internal transcribed spacer (ITS) region of rDNA followed by RFLP $(8,10,29,41,52)$ have also been used. A very effective reverse dot blot hybridization system that employs species-specific oligonucleotides immobilized on a membrane (32) for rapid Pythium species identification has been developed but is not available for routine clinic use. Therefore, species identification remains a major problem in most clinics. It is usually assumed that any Pythium found in a sample is a pathogen, and management recommendations are made accordingly. As a result, little is known about which Pythium species are causing crop losses, whether certain species are associated with particu- lar crops, or if fungicide resistance is prevalent in particular species.

Historical data on species isolated and hosts infected by particular species may not reflect the present situation because of the significant cultural practice changes that have occurred in the industry. Beginning in the 1970 s, most greenhouse operators ceased using field soil as a potting mix component in favor of using peat moss, vermiculite, perlite, and many components to prepare "soilless" potting media. Furthermore, the industry now grows a vast array of cultivars in each crop species, and these can vary greatly in relative susceptibility to pathogens. It was reported (50) that in California during the 1940s, P. ultimum was isolated in the greatest frequency from poinsettia cuttings but that $P$. debaryanum, $P$. perniciosum, and $P$. irregulare were also found. Similarly in the $1950 \mathrm{~s}, P$. ultimum was the most frequently isolated organism from poinsettias and lilies in Michigan greenhouses (44). P. splendens was a serious pathogen on geraniums, chrysanthemums, and begonias in Canada in the late 1970s (6), and of the several species encountered on geranium cuttings, including $P$. aphanidermatum, $P$. irregulare, and others, $P$. splendens was most pathogenic (39). A survey of greenhouse-grown bedding plants affected by damping-off in Ohio during 1974 and 1975 found 11 cases caused by P. ultimum, 3 by $P$. irregulare, 1 by $P$. aphanidermatum, and 2 by an unidentified species of Pythium (47). It is recognized that species of Pythium seldom exhibit host specificity $(6,24)$ and isolates within species vary in pathogenicity and virulence on varieties of specific crops $(7,35)$.

To document which species of Pythium have been associated with greenhouse crop losses in Pennsylvania during 1996 to 2001, isolates obtained from samples submitted for diagnosis were identified using morphological features and the sequences of a region (ITS1, 5.8S, and ITS2) of the ribosomal DNA (rDNA). To determine whether the sequence of another segment of DNA could be used for identifying species, part of the ras-related protein gene (2) was sequenced. A preliminary report on the ras-related protein gene in selected species of Pythium and Phytophthora was published (56). The sensitivity of all isolates to mefenoxam, a widely used isomer of the phenylamide fungicide metalaxyl, was tested. 


\section{MATERIALS AND METHODS}

Isolations. Samples submitted to the Penn State Plant Disease Clinic and the Pennsylvania Department of Agriculture, Bureau of Plant Industry, by growers, county agents, and plant inspectors during 1996 to 2001 were processed in a number of different ways in order to detect the presence of Pythium and isolate the organism. Usually, roots of plant samples were washed in running tap water, blotted dry, and plated onto water agar (WA), PPP agar $(0.10 \mathrm{~g}$ of pimaricin, $0.05 \mathrm{~g}$ of penicillin, and $0.05 \mathrm{~g}$ of polymyxin per liter in corn meal agar [17]), or PARP agar (0.005 $\mathrm{g}$ of pimaricin, $0.25 \mathrm{mg}$ of ampicillin, $0.01 \mathrm{~g}$ of rifampicin, and $0.10 \mathrm{~g}$ of pentachloronitrobenzene per liter in corn meal agar [28]). and thoroughly moistened with tap water. To each bag was added two 10-mmdiameter, 50-mm-long plugs of potato cut with a sterile cork borer from a washed, surface-disinfected, peeled tuber. After a 24-h room temperature incubation period, the plugs were rinsed in running tap water, Soil samples were placed in plastic bags

and four lengthwise slices were removed from the surface and plated onto PARP. Water samples (500 to $1,000 \mathrm{ml}$ ) were aspirated, using a Buchner funnel, through filter paper (VWR brand No. 413) that retains 5- $\mu \mathrm{m}$ or larger particles. The filter paper was then inverted onto PARP. Following incubation of the roots, bait, or filter paper, coenocytic hyphae were transferred to WA or PARP to eliminate bacteria and other contaminants. For storage at room temperature, pure cultures were transferred to WA and grown for 2 to 3 weeks, and then the agar was cut into small blocks and placed in tubes of sterile tap water.

Isolates of known identity. Isolates of known identity were obtained from the Centre for Agriculture Biosciences International collection (UK), H. H. Ho (State University of New York, New Paltz), J. W. Hoy (Louisiana State University) and the 1993 APS Pythium identification workshop held in Nashville, TN.

Identification. To prepare all isolates of known identity and those from greenhouse

Table 1. Pythium species' ITS1, 5.8S, and ITS2 ribosomal DNA and ras-related protein gene sequences were determined in this study and used to establish a database to identify unknown species through sequence comparisons. Sequences are available in the National Center for Biotechnology Information database, GenBank (available on-line)

\begin{tabular}{|c|c|c|c|}
\hline \multirow[b]{2}{*}{ Pythium species } & \multirow[b]{2}{*}{ Isolate designation } & \multicolumn{2}{|c|}{ GenBank accession no. } \\
\hline & & rDNA sequences & $\begin{array}{l}\text { ras-related protein } \\
\text { gene sequences }\end{array}$ \\
\hline aphanidermatum & aphanTN (PSU) & & AF454357 \\
\hline aphanidermatum & 100439R (CABI) & AF452149 & \\
\hline aphanidermatum & 141749R (CABI) & AF442146 & \\
\hline arrhenomanes & arrhenTN (PSU) & & AF454356 \\
\hline catenulatum & catenTN (PSU) & & AF454359 \\
\hline cylindrosporum & 80171-91 (PDA) & & AF454364 \\
\hline deliense & 20-1 (Hoy) & AF452147 & AF454355 \\
\hline dissotocum & 360198R (CABI) & AF452154 & \\
\hline graminicola & $\operatorname{gramTN}(\mathrm{PSU})$ & & AF454362 \\
\hline helicoides & P13 (PSU) & AF452138 & \\
\hline heterothallicum & 285 (Ноy) & AF452162 & \\
\hline irregulare & P40 (PSU) & AF382820 & \\
\hline & MYA-2136 (ATCC) & & \\
\hline irregulare & P03 (PSU) & AF385834 & \\
\hline & MYA-2133 (ATCC) & & \\
\hline irregulare & 363670R (CABI) & AF452143 & \\
\hline irregulare & 371144R (CABI) & AF452141 & \\
\hline macrosporum & P01 (PSU) & AF45145 & \\
\hline myriotylum & P30 (PSU) & AF452156 & AF454360 \\
\hline & MYA-2135 (ATCC) & & \\
\hline spinosum & 1499 (Ноy) & AF452144 & \\
\hline spinosum & $86-43(\mathrm{Ho})$ & & AF454363 \\
\hline splendens & $86-275(\mathrm{Ho})$ & & AF454366 \\
\hline sylvaticum & 31043-99 (PDA) & AF452140 & \\
\hline torulosum & $18-5$ (Hoy) & AF452155 & AF454358 \\
\hline ultimum var. sporangiiferum & $2180-80$ (PDA) & AF452157 & \\
\hline ultimum var. sporangiiferum & 308276R (CABI) & AF452163 & \\
\hline ultimum var. ultimum & ATCC 32231 & AF452160 & AF454365 \\
\hline ultimum var. ultimum & P17 (PSU) & AF452159 & \\
\hline & MYA-2134 (ATCC) & & \\
\hline ultimum var. ultimum & 342645R (CABI) & AF452161 & \\
\hline ultimum var. ultimum & 369357R (CABI) & AF452158 & \\
\hline vanterpoolii & vantTN (PSU) & & AF454361 \\
\hline vexans & $81708-98$ (PDA) & AF452136 & \\
\hline
\end{tabular}

a ATCC = American Type Culture Collection; CABI = Centre for Agriculture Biosciences International; Ho = H. H. Ho, State University of New York, New Paltz; Hoy = J. W. Hoy, Louisiana State University; PSU = The Pennsylvania State University, Department of Plant Pathology; PDA = Pennsylvania Department of Agriculture, Bureau of Plant Industry. samples for morphological identification, rye (Secale cereale L.) seed was germinated and grown for several days in the lab. Leaf blades were cut into 10-mm lengths and boiled for $10 \mathrm{~min}$ in distilled water. The boiled blades, suspended in sterile, $10 \%$ soil extract in $35-\mathrm{mm}$ diameter petri plates, were inoculated and incubated at room temperature. Morphological features were examined 3 to 21 days later, depending upon the isolate, and identifications were based on the key of van der Plaats-Niterink (51).

To prepare isolates for DNA extraction, a small piece of colonized agar was transferred to $50 \mathrm{ml}$ of sterile, $20 \% \mathrm{~V} 8$ juice broth in a 125-ml Erlenmeyer flask and grown in shake culture $(100 \mathrm{rpm})$ at room temperature for 3 to 7 days. The mycelium was poured onto filter paper in a Buchner funnel and rinsed thoroughly with tap water during aspiration. The mycelium was then removed from the filter paper, placed in liquid nitrogen, and ground to a fine powder with a mortar and pestle. The powder was transferred to microcentrifuge tubes to which DNAzol ES (Molecular Research Center, Inc., Cincinnati, $\mathrm{OH}$ ) was added. Tubes were stored at $4^{\circ} \mathrm{C}$ for 2 to 7 days until DNA was extracted according to the manufacturer's protocol. The final DNA pellet was resuspended in $10 \mathrm{mM}$ Tris- $\mathrm{HCl}$ buffer $(\mathrm{pH} 8)$ and stored at $-80^{\circ} \mathrm{C}$.

Part of the $18 \mathrm{~S}$ region, all of the internal transcribed spacers and 5.8S regions, and part of the 28S region of rDNA were amplified using PCR as follows. A 50- $\mu$ l reaction consisting of $5 \mu \mathrm{l}$ of buffer $(0.1 \mathrm{M}$ Tris- $\mathrm{HCl}, \mathrm{pH} 8.3,0.5 \mathrm{M} \mathrm{KCl}, 0.025 \mathrm{M}$ $\mathrm{MgCl}_{2}$ ), $5 \mu \mathrm{l}$ containing $2 \mathrm{mM}$ of each $\mathrm{dNTP}, 1 \mu \mathrm{l}$ of $10 \mu \mathrm{M}$ ITS-1 primer (5'tccgtaggtgaacetgcgg- $\left.3^{\prime}\right), 1 \mu \mathrm{l}$ of $10 \mu \mathrm{M}$ ITS2 primer $\left(5^{\prime}\right.$-gctgcgttcttcatcgatgc- $\left.3^{\prime}\right)$ (55), $0.1 \mu \mathrm{l}$ of Taq polymerase, $27.9 \mu \mathrm{l}$ of deionized, filter-sterilized water, and $10 \mu \mathrm{l}$ of 1:100 dilution of DNA template (1 part DNA in $10 \mathrm{mM}$ Tris-HCl buffer:99 parts deionized, filter-sterilized water) was done in $0.2 \mathrm{ml}$, thin-walled microcentrifuge tubes. Thermal cycling (MJ Research, Inc., model PTC-100, Watertown, MA) parameters were $94^{\circ} \mathrm{C}, 5 \mathrm{~min}$; followed by 34 cycles of $94^{\circ} \mathrm{C}, 1 \mathrm{~min} ; 53^{\circ} \mathrm{C}, 1 \mathrm{~min}$; and $72^{\circ} \mathrm{C}, 1 \mathrm{~min}$; and was completed with $72^{\circ} \mathrm{C}$ for $5 \mathrm{~min}$ followed by $4^{\circ} \mathrm{C}$. Amplification of a portion of the ras-related protein gene was performed in a 50- $\mu$ l reaction as above using the primers ypt-1 (5'-ctactg atcggtgactctgg- $\left.3^{\prime}\right)$ and ypt-4 (5'-ggctgt gagatcgctcttgt- $\left.3^{\prime}\right)$. These primers were designed by the authors based in part on the sequence for Phytophthora infestans (11) (NCBI GenBank accession no. U30474) to amplify all of introns 3, 4, and 5 of Phytophthora infestans. Thermal cycling parameters were $94^{\circ} \mathrm{C}, 2 \mathrm{~min}$; followed by 43 cycles of $94^{\circ} \mathrm{C}, 1 \mathrm{~min} ; 56^{\circ} \mathrm{C}$, $1 \mathrm{~min}$; and $72^{\circ} \mathrm{C}, 1 \mathrm{~min}$; and was completed with $72^{\circ} \mathrm{C}$ for $5 \mathrm{~min}$ followed by 
$4^{\circ} \mathrm{C}$. PCR products were purified using Qiaquick spin columns (Qiagen, Inc., Valencia, CA). DNA sequencing was performed on both strands using ABI Prism (ABI/Perkin-Elmer; Applied Biosystems, Foster City, CA) Dye Terminator Cycle Sequencing Ready Reaction Kits for a 5- $\mu \mathrm{l}$ reaction.

The ITS1, 5.8S, and ITS2 region rDNA sequences determined for isolates of known identity, those from some readily identified isolates obtained during this work, and others already in GenBank formed a Pythium-only database using the DNASTAR software Megalign program (DNASTAR Inc., Madison, WI) used in identifying unknowns. Sequences from some of the known isolates and isolates obtained here (Table 1) were deposited in the National Center for Biotechnology Information (NCBI) database (GenBank, available on-line).

Fungicide resistance. The sensitivity of isolates to mefenoxam, an isomer of metalaxyl, was tested in vitro. Corn meal agar (CMA) was amended with $100 \mu \mathrm{g}$ of mefenoxam per $\mathrm{ml}$ by suspending Subdue Maxx (21.3\% mefenoxam; Syngenta) in water and distributing it into molten agar prior to pouring it into petri plates. Upon cooling, the plates were inoculated by inverting a 10 -mm-diameter block of colonized CMA that had been cut with a sterile cork borer from a culture onto the center of each plate. Two fungicide-free plates and 2 plates containing fungicide for each isolate were incubated in the dark at $25^{\circ} \mathrm{C}$ for 18 to $48 \mathrm{~h}$, depending upon the isolate growth rate. Growth was measured from the inoculum block to the edge of the colony along two random radii per plate. Each isolate was tested at least twice. If $100 \mu \mathrm{g}$ of metalaxyl or mefenoxam per $\mathrm{ml}$ does not slow an isolate's growth by $50 \%$ compared with growth in the absence of fungicide $\left(\mathrm{EC}_{50}>100 \mu \mathrm{g} / \mathrm{ml}\right)$, it is considered fungicide-resistant (42).

\section{RESULTS}

During 1996 to 2001, 120 samples submitted to two clinics in Pennsylvania involved 11 different Pythium species and 2 unidentified isolates (Table 2). Samples included 110 plants from 36 different species of crops (Table 3), five unused potting media tests, and five tests of irrigation water. P. irregulare was found in $45 \%$ of the plant samples (23 different crop species) received as well as four of the five water and three of the five potting media samples. P. irregulare was found on 15 of the 26 geranium (Pelargonium) samples submitted. The remaining geranium samples received were infected with six other species: one $P$. aphanidermatum, three $P$. dissotocum, one $P$. heterothallicum, one group $\mathrm{F}$, three $P$. myriotylum, and two $P$. ultimum. $P$. aphanidermatum accounted for 32 cases (29\% of plant samples), 30 of which were on poinsettias (Euphorbia pulcherrima; $77 \%$ of the poinsettia samples). The remaining nine poinsettia samples were infected with seven $P$. irregulare, one group $\mathrm{G}$, and one $P$. ultimum.

DNA sequences from the ITS1, 5.8S, and ITS2 regions of rDNA were readily obtained from all species except some isolates of $P$. irregulare. While the sequences from $P$. ultimum and $P$. irregulare isolates exhibited some variation within each of those species, sequences from $P$. aphanidermatum isolates were essentially identical to one another (data not shown). Ribosomal DNA sequences readily differentiated all known species encountered in this study. The few intraspecific differences in $P$. ultimum and $P$. irregulare were insufficient to differentiate populations.

This is the first report of sequences for portions of the ras-related protein gene in Pythium. The PCR products ranged in size from 375 to $525 \mathrm{bp}$. PCR products could not be obtained for $P$. dissotocum, $P$. helicoides, $P$. irregulare, or $P$. heterothallicum. Therefore, this portion of the DNA could not be used to differentiate all species found in this study. Among the species successfully amplified, the sequences differed significantly from one another in most cases. Intron 4, found in Phytophthora infestans, was not present in Pythium catenulatum, P. cylindrosporum, $P$. graminicola, $P$. myriotylum, $P$. spinosum, $P$. torulosum, or $P$. vanterpoolii. The sequences for Pythium aphanidermatum, $P$. arrhenomanes, and $P$. deliense were essentially identical and could not be used to differentiate these species from one another.

Of the $32 P$. aphanidermatum isolates, 12 were resistant to mefenoxam while 21 of the $57 P$. irregulare isolates were resistant. One isolate each of $P$. cylindrosporum, $P$. dissotocum, $P$. heterothallicum, $P$. splendens, $P$. ultimum, and one of the

Table 2. Species of Pythium isolated from plant, soil, and water samples submitted to the Pennsylvania Department of Agriculture, Bureau of Plant Industry, and The Pennsylvania State University plant disease clinics in 1996 to 2001 and the number found to be resistant to mefenoxam

\begin{tabular}{lcc}
\hline Pythium species & $\begin{array}{c}\text { No. of } \\
\text { samples }\end{array}$ & $\begin{array}{c}\text { No. resistant to } \\
\text { mefenoxam }^{\mathbf{a}}\end{array}$ \\
\hline aphanidermatum & 32 & 12 \\
cylindrosporum & 1 & 1 \\
dissotocum & 4 & 1 \\
Group F & 1 & 0 \\
heterothallicum & 1 & 1 \\
irregulare & 57 & 21 \\
myriotylum & 6 & 0 \\
sylvaticum & 2 & 0 \\
splendens & 1 & 1 \\
ultimum & 13 & 1 \\
Unknown species & 2 & 1 \\
Total & 120 & 39 \\
\hline
\end{tabular}

${ }^{a}$ Growth in the presence of $100 \mu \mathrm{g} / \mathrm{ml} \mathrm{me-}$ fenoxam in corn meal agar was not slowed by $50 \%$ as compared to growth on fungicide-free $\operatorname{agar}\left(\mathrm{EC}_{50}>100 \mu \mathrm{g} / \mathrm{ml}\right)$ unidentified isolates were also resistant to mefenoxam (Table 2).

\section{DISCUSSION}

A greenhouse crop may come in contact with Pythium from a number of different sources including peat moss $(19,30)$, soil (26), irrigation water $(43,45,48)$, movement by fungus gnats (Bradysia impatiens) and shoreflies (Scatella stagnalis) (20,22,27), or contaminated soil on greenhouse floors

Table 3. Plants, soil, and water samples containing Pythium submitted to the Pennsylvania Department of Agriculture, Bureau of Plant Industry, and The Pennsylvania State University plant disease clinics in 1996 to 2001

\begin{tabular}{|c|c|}
\hline Sample submitted & $\begin{array}{l}\text { No. of samples- } \\
\text { species isolated }\end{array}$ \\
\hline Adiantum, fern & 1-P. irregulare \\
\hline $\begin{array}{l}\text { Antirrhinum, } \\
\text { snapdragon }\end{array}$ & $\begin{array}{l}\text { 1-P. cylindrosporum } \\
\text { 3-P. irregulare } \\
1-P . \text { ultimum }\end{array}$ \\
\hline Aquilegia & 1-P. irregulare \\
\hline Athyrium, fern & 1-P. irregulare \\
\hline Begonia & 1-P. ultimum \\
\hline Bellis & 1-P. irregulare \\
\hline Bidens & 1-P. myriotylum \\
\hline Bacopa & $\begin{array}{l}1-P . \text { irregulare } \\
1-P . \text { ultimum }\end{array}$ \\
\hline Chrysanthemum & $\begin{array}{l}\text { 3-P. irregulare } \\
1-P . \text { ultimum }\end{array}$ \\
\hline Cordyline & 1-P. irregulare \\
\hline Cyclamen & 1-P. irregulare \\
\hline Dianthus & 1-P. myriotylum \\
\hline Digitalis & 1-P. myriotylum \\
\hline $\begin{array}{l}\text { Euphorbia, } \\
\text { poinsettia }\end{array}$ & $\begin{array}{l}\text { 30-P. aphanidermatum } \\
\text { 7-P. irregulare } \\
\text { 2-P. ultimum }\end{array}$ \\
\hline Gerbera & 1-P. irregulare \\
\hline Helianthemum & 1-P. irregulare \\
\hline Heuchera & 2-P. irregulare \\
\hline Impatiens & 2-P. irregulare \\
\hline Lilium, Easter lily & 1-P. ultimum \\
\hline Lupinus & 1-P. irregulare \\
\hline Matteuccia, fern & 1-P. ultimum \\
\hline Ocimum basilicum & 1-P. irregulare \\
\hline Osmunda, fern & 1-P. irregulare \\
\hline $\begin{array}{l}\text { Pelargonium, } \\
\text { ivy geranium }\end{array}$ & 1-P. dissotocum \\
\hline $\begin{array}{l}\text { Pelargonium, } \\
\text { zonal geranium }\end{array}$ & $\begin{array}{l}\text { 1-P. aphanidermatum } \\
\text { 2-P. dissotocum } \\
\text { 1-Group F } \\
\text { 1-P. heterothallicum } \\
\text { 15-P. irregulare } \\
\text { 3-P. myriotylum } \\
\text { 2-P. ultimum }\end{array}$ \\
\hline Petunia & 1-P.dissotocum \\
\hline Pulmonaria & 1-P. irregulare \\
\hline Ranunculus & 1-P. irregulare \\
\hline Rosa, miniature rose & 1-Pythium sp. \\
\hline Salvia & 1-P. ultimum \\
\hline Schlumbergera & $\begin{array}{l}\text { 1-P. aphanidermatum } \\
1-P . \text { irregulare }\end{array}$ \\
\hline Sedum & 2-P. irregulare \\
\hline Thymus & 1-P. irregulare \\
\hline Verbena & 1-P. ultimum \\
\hline Viola & 1-Pythium sp. \\
\hline Zinnia & 1-P. irregulare \\
\hline Unused potting soil & $\begin{array}{l}\text { 3-P. irregulare } \\
1-P . \text { splendens } \\
1-P . \text { sylvaticum }\end{array}$ \\
\hline Irrigation water & $\begin{array}{l}\text { 4-P. irregulare } \\
1-P . \text { sylvaticum }\end{array}$ \\
\hline Total & 120 \\
\hline
\end{tabular}


(46). The organism may also be brought into the facility from long distances when cuttings, seedlings, or potted plants are infected during propagation at one facility and then sold to another greenhouse. Thus, knowing what species are common in a given outdoor locale or even a region may provide little insight on what species actually are found in a particular greenhouse. This coupled with the fact that some species of Pythium are very pathogenic while others are not makes it important to identify the species of Pythium actually present on greenhouse plants exhibiting disease symptoms and those found in water or potting media used in the greenhouse. Historical data indicate that $P$. ultimum was a very common cause of crop losses. In contrast, we found that $P$. irregulare and $P$. aphanidermatum are currently responsible for the majority of Pythium cases submitted to clinics in Pennsylvania. However, some care should be exercised in judging the relative importance of the Pythium species presented here. In most cases, samples submitted to clinics are not collected at random. Rather, samples are usually submitted because the plants exhibit obvious symptoms indicating a root disease is occurring. Isolates may have been the primary cause of disease or merely associated with plants whose health was compromised by other factors. The severity of the Pythium-plant interaction can depend greatly on growing conditions (40). Finally, species of Pythium that tend to stunt plants or cause symptoms too mild to be noted by other than the most discriminating greenhouse operator may be underrepresented here.

The association of Pythium aphanidermatum with poinsettias, although not a new report (5), is noteworthy because of the extensive interdependence of the poinsettia production system. Relatively few specialty propagators maintain stock plants and are the sources of large numbers of cuttings sold to secondary propagators and greenhouse operators who finish the plants for holiday sales. It is not known at this time whether $P$. aphanidermatum is particularly pathogenic on poinsettias, whether the cultural conditions for poinsettias favor infection by $P$. aphanidermatum as opposed to other Pythium species, or whether $P$. aphanidermatum is infecting plants early in the production cycle and then inadvertently spread to other greenhouse operations on cuttings. There is extremely little variation among $P$. aphanidermatum isolates' rDNA sequences. Research is underway using AFLP and other molecular techniques to identify populations within species so that the movement of this serious pathogen can be traced in the industry (21).

It was found here that by comparing the sequences of the ITS1, 5.8S, and ITS2 regions of rDNA from isolates of unknown identity to sequences from known species, almost all the isolates could be readily identified to species. Two isolates could not be identified and may be new species. As rDNA sequences from additional morphologically verified species of Pythium are added to GenBank, anyone with DNA sequencing facilities or sequencing services will be able to identify isolates quickly, regardless of their ability to produce and recognize morphological features of the organism. It is recommended that those working with Pythium populations extract DNA and store it for use in species identification and population characterization employing current molecular methods and for future use with methods as yet to be developed.

To our knowledge, this is the first report of PCR amplification and DNA sequencing of a portion of the ras-related protein gene in species of Pythium. The primers used here, based on the published Phytophthora infestans sequence (11), successfully amplified all of introns 3,4 , and 5 of an isolate of Phytophthora infestans (data not shown) and several $P y$ thium species. The ras-related protein gene has been studied extensively because of its presence in a large number of very diverse organisms and because of its role in the development of cancer (2) but has not been used in species identification. In the present study, these sequences were less informative than those of the ITS region for Pythium identification and therefore are not useful in identification of Pythium species. It is possible that areas corresponding to introns 1 and 2 in Phytophthora infestans could provide significantly more information.

Mefenoxam and its isomer, metalaxyl, have been important chemicals used by greenhouse operators to protect a wide variety of crops against Oomycetes. Our finding that almost $40 \%$ of the P. aphanidermatum and $P$. irregulare isolates have resistance to this chemical is important because these two species were encountered in $74 \%$ of all Pythium cases from 1996 through 2001 in Pennsylvania, a production area typical of the northeastern United States and not unlike those elsewhere in North America. If Pythiuminfected plant material is being inadvertently shared among growers, it is likely that fungicide-resistant isolates are being moved throughout the industry as well. As a result, even growers who seldom use mefenoxam may discover that the chemical does not effectively protect their crops because a resistant population was brought into the facility on plant material. Also of concern is the finding that at least one isolate of several other species, including P. ultimum, were resistant. Pythium isolate resistance to mefenoxam should be checked routinely before suggesting the use of that chemical in root rot management.
ACKNOWLEDGMENTS

We thank R. Lease for technical assistance throughout this work, M. Yoneyama for the initial research on the ras-related protein gene in $P y$ thium, A. Lévesque for corroborating ITS sequence information, and G. Saddler (CABI), J. W. Hoy (Louisiana State University), and H. Ho (University of New York, New Paltz) for providing isolates of known identity. We gratefully acknowledge the generous funding of this project by the American Floral Endowment and The Fred C. Gloeckner Foundation Inc. This work was initiated with financial assistance from the Pennsylvania Floral Industry Association and The Pennsylvania State University Agricultural Experiment Station.

\section{LITERATURE CITED}

1. Adaskaveg, J. E., Stanghellini, M. E. Gilbertson, R. L., and Egen, N. B. 1988. Comparative protein studies of several $P y$ thium spp. by isoelectric focusing. Mycologia 80:665-672.

2. Barbacid, M. 1987. ras Genes. Annu. Rev. Biochem. 56:779-827.

3. Barr, D. J. S., Warwick, S. I., and Desaulniers, N. L. 1998. Isozyme variation in heterothallic species and related asexual isolates of $P y$ thium. Can. J. Bot. 75:1927-1935.

4. Belkhiri, A., and Dick, M. W. 1988. Comparative studies of the DNA of Pythium species and some possibly related taxa. J. Gen. Microbiol. 134:2673-2683.

5. Bolton, A. T. 1978. Sudden wilting of poinsettia (Euphorbia pulcherrima) caused by $P y$ thium aphanidermatum. Can. J. Plant Sci. 58:569-570.

6. Bolton, A. T. 1981. Specificity among isolates of Pythium splendens from geranium, chrysanthemum, Reiger begonia. Can. J. Plant Pathol. 3:177-179.

7. Chagnon, M.-C., and Bélanger, R. R. 1991. Tolerance in greenhouse geraniums to $P y$ thium ultimum. Plant Dis. 75:820-823.

8. Chen, W. 1992. Restriction fragment length polymorphisms in enzymatically amplified ribosomal DNAs of three heterothallic Pythium species. Phytopathology 82:1467-1472.

9. Chen, W., Hoy, J. W., and Schneider, R. W. 1991. Comparison of soluble protein electrophoresis and isozyme analysis and their potential application to Pythium systematics. Mycol. Res. 95:548-555.

10. Chen, W., Hoy, J. W., and Schneider, R. W. 1992. Species-specific polymorphisms in transcribed ribosomal DNA of five Pythium species. Exp. Mycol. 16:22-34.

11. Chen, Y., and Roxby, R. 1996. Characterization of a Phytophthora infestans gene involved in vesicle transport. Gene 181:89-94.

12. Clare, B. G. 1963. Starch gel electrophoresis of protein as an aid in identifying fungi. Nature 200:803-804.

13. Clare, B. G., Flentje, N. T., and Atkinson, M. R. 1968. Electrophoretic patterns of oxidoreductases and other proteins as criteria in fungal taxonomy. Aust. J. Biol. Sci. 21:275-295.

14. Csinos, A. 1979. Non-parasitic pathogenesis of germinating tomato by Pythium myriotylum. Can. J. Bot. 57:2059-2063.

15. Csinos, A., and Hendrix, J. W. 1978. Parasitic and non-parasitic pathogenesis of tomato plants by Pythium myriotylum. Can. J. Bot. 56:2334-2339.

16. Dick, M. W. 1990. Keys to Pythium. University of Reading, Reading, UK.

17. Eckert, J. W., and Tsao, P. H. 1962. A selective antibiotic medium for isolation of Phy tophthora and Pythium from plant roots. Phytopathology 52:771-777.

18. Farr, D. F., Bills, G. F., Chamuris, G. P., and Rossman, A. Y. 1989. Fungi on Plants and Plant Products in the United States. American Phytopathological Society, St. Paul, MN. 
19. Favrin, R. J., Rahe, J. E., and Mauza, B. 1988. Pythium spp. associated with crown rot of cucumbers in British Columbia greenhouses. Plant Dis. 72:683-687.

20. Gardiner, R. B., Jarvis, W. R., and Shipp, J. L. 1990. Ingestion of Pythium spp. by larvae of the fungus gnat Bradysia impatiens (Diptera, Sciaridae). Ann. Appl. Biol. 116:205-212.

21. Garzón, C. D., Geiser, D. M., and Moorman, G. W. 2001. Characterization of Pythium species using AFLPs. (Abstr.) Phytopathology 91:S31.

22. Goldberg, N. P., and Stanghellini, M. E. 1990. Ingestion-egestion and aerial transmission of Pythium aphanidermatum by shore flies (Ephydrinae: Scatella stagnalis). Phytopathology 80:1244-1246.

23. Hendrix, F. F., and Campbell, W. A. 1970. Distribution of Phytophthora and Pythium species in soils in the continental United States. Can. J. Bot. 48:377-384.

24. Hendrix, F. F., and Campbell, W. A. 1973. Pythiums as plant pathogens. Annu. Rev. Phytopathol. 11:77-98.

25. Herrero, M. L., and Klemsdal, S. S. 1998. Identification of Pythium aphanidermatum using the RAPD technique. Mycol. Res. 102:136-140.

26. Hoppe, P. E. 1959. Pythium species still living in muck soil air-dried six years. Phytopathology 49:830-831.

27. Jarvis, W. R., Shipp, J. L., and Gardiner, R. B. 1993. Transmission of Pythium aphanidermatum to greenhouse cucumber by the fungus gnat Bradysia impatiens (Diptera, Sciaridae). Ann. Appl. Biol. 122:23-29.

28. Jeffers, S. N., and Martin, S. B. 1986. Comparison of two media selective for Phytophthora and Pythium species. Plant Dis. 70:1038-1043.

29. Kageyama, K., Uchino, H., and Hyakumachi, M. 1998. Characterization of the hyphal swelling group of Pythium: DNA polymorphisms and cultural and morphological characteristics. Plant Dis. 82:218-222.

30. Kim, S. H., Forer, L. B., and Longenecker, J. L. 1975. Recovery of plant pathogens from commercial peat products. Proc. Am. Phytopathol. Soc. 2:124

31. Lévesque, C. A., Beckenbach, K., Baillie, D. L., and Rahe, J. E. 1993. Pathogenicity and DNA restriction fragment length polymor- phisms of isolates of Pythium spp. from glyphosate-treated seedlings. Mycol. Res. 97:307-312.

32. Lévesque, C. A., Harlton, C. E., and de Cock, A. W. A. M. 1998. Identification of some oomycetes by reverse dot blot hybridization. Phytopathology 88:213-222.

33. Martin, F. N. 1990. Taxonomic classification of asexual isolates of Pythium ultimum based on cultural characteristics and mitochondrial DNA restriction patterns. Exp. Mycol. 14:4756.

34. Martin, F. N., and Kistler, H. C. 1990. Species specific banding patterns of restriction endonuclease digested mitochondrial DNA in the genus Pythium. Exp. Mycol. 14:32-46.

35. McCarter, S. M., and Littrell, R. H. 1970. Comparative pathogenicity of Pythium aphanidermatum and Pythium myriotylum to twelve plant species and intraspecific variation in virulence. Phytopathology 60:264-268.

36. McNabb, S. A., Boyd, P. A., Belkhiri, A., Dick, M. W., and Klassen, G. R. 1987. An inverted repeat comprises more than threequarters of the mitochondrial genome in two species of Pythium. Curr. Genet. 12:205-208.

37. McNabb, S. A., and Klassen, G. R. 1988. Uniformity of mitochondrial DNA complexity in Oomycetes and the evolution of the inverted repeat. Exp. Mycol. 12:233-242.

38. Middleton, J. T. 1943. The taxonomy, host range and geographic distribution of the genus Pythium. Mem. Torrey Bot. Club 20:1-171.

39. Miller, H. N., and Sauve, R. J. 1975. Etiology and control of Pythium stem rot of geranium. Plant Dis. Rep. 59:122-126.

40. Moorman, G. W. 1986. Increased plant mortality caused by Pythium root rot of poinsettia associated with high fertilization rates. Plant Dis. 70:160-162.

41. Mugnier, J., and Grosjean, M. C. 1995. PCR catalogue in Plant Pathology: Pythium. Rhone-Poulenc Agro, Lyon, France.

42. Sanders, P. L. 1984. Failure of metalaxyl to control Pythium blight on turfgrass in Pennsylvania. Plant Dis. 68:776-777.

43. Sanogo, S., and Moorman, G. W. 1993. Transmission and control of Pythium aphanidermatum in an ebb-and-flow subirrigation system. Plant Dis. 77:287-290.

44. Scheffer, R. P., and Haney, W. J. 1956. Causes and control of root rot in Michigan green- houses. Plant Dis. Rep. 40:570-579.

45. Stanghellini, M. E., and Kronland, W. C. 1986. Yield loss in hydroponically grown lettuce attributed to subclinical infection of feeder rootlets by Pythium dissotocum. Plant Dis. 70:1053-1056.

46. Stephens, C. T., Herr, L. J., Schmitthenner, A F., and Powell, C. C. 1983. Sources of Rhizoc tonia solani and Pythium spp. in a bedding plant greenhouse. Plant Dis. 67:272-275.

47. Stephens, C. T., and Powell, C. C. 1982 Pythium species causing damping-off of seedling bedding plants in Ohio greenhouses. Plant Dis. 66:731-733.

48. Sultan, Y. 1988. Rhythm of zoospore production of Pythium on lettuce cultured hydroponicaly. M.S. thesis. Department of Plant Pathology, University of Arizona, Tucson.

49. Tompkins, C. M. 1975. World literature on Pythium and Rhizoctonia species and the diseases they cause. Contr. Reed Herbarium 24:1-69.

50. Tompkins, C. M., and Middleton, J. T. 1950. Etiology and control of poinsettia root and stem rot caused by Pythium spp. and Rhizoctonia solani. Hilgardia 20:171-182.

51. van der Plaats-Niterink, A. J. 1981. Monograph of the genus Pythium. Vol. 21, Studies in Mycology. Centraalbureau Voor Schimmelcultures, Baarn, The Netherlands.

52. Wang, P. H., and White, J. G. 1997. Molecular characterization of Pythium species based on RFLP analysis of the internal transcribed spacer region of ribosomal DNA. Physiol. Mol. Plant Pathol. 51:129-143.

53. Waterhouse, G. M. 1967. Key to Pythium Pringsheim. Mycol. Pap. 109:1-15.

54. Waterhouse, G. M. 1968. The genus Pythium Diagnoses (or descriptions) and figures from the original papers. Mycol. Pap. 110:1-50.

55. White, T. J., Bruns, T., Lee, S., and Taylor, J. 1990. Amplification and direct sequencing of fungal ribosomal RNA genes for phylogenetics. Pages 315-322 in: PCR Protocols, A Guide to Methods and Application. M. A. Innis, D. H. Gelfand, J. J. Sninsky, and T. J. White, eds. Academic Press, San Diego.

56. Yoneyama, M., Lease, R., Geiser, D., Kang, S., Moorman, G., and Kim, S. 2000. Comparison of the ras-related protein gene sequence among species of Pythium and Phytophthora. (Abstr.) Phytopathology 90:S87. 